\title{
PHYSICOCHEMICAL CHARACTERISTICS OF MEAT OF NELLORE STEERS SUPPLEMENTED WITH OR WITHOUT ADDITION OF LIPIDS
}

\author{
CARACTERISTICAS FÍSICO-QUIMMICA DA CARNE DE NOVILHOS NELORE \\ SUPLEMENTADOS COM OU SEM ADIÇÃO DE LIPÍDIOS
}

\author{
Clóvis Carlos SILVEIRA FILHO ${ }^{1}$; Carlos Augusto de Alencar FONTES ${ }^{1 \dagger}$; \\ Elizabeth Fonsêca PROCESSI ${ }^{1}$; Laila Cecília Ramos BENDIA ${ }^{1}$; \\ Cláudio Teixeira LOMBARDI ${ }^{2}$; Paulo Roberto Silveira PIMENTEL ${ }^{2}$; \\ Ronaldo Lopes OLIVEIRA ${ }^{2}$; Leilson Rocha BEZERRA ${ }^{3}$; Tiago Cunha ROCHA ${ }^{4^{*}}$ \\ 1. State University of North Fluminense Darcy Ribeiro, Department of Animal Science, Campos dos Goytacazes, Rio de Janeiro, Brazil. \\ †in memoriam. 2. Federal University of Bahia, Department of Animal Science, Salvador, Bahia, Brazil; 3. Federal University of \\ Campina Grande, Center of Health and Agricultural Technology, Patos, Paraíba, Brazil; 4. State University of the Tocantina Region of \\ Maranhão, Imperatriz, Maranhão, Brazil. *tiagoticuro@yahoo.com.br
}

\begin{abstract}
The aim of research was to evaluate the meat quality of Nellore young bulls in grazing supplemented with or without addition of lipids. Twenty-four young bulls, $301 \pm 5.8 \mathrm{~kg}$ in body weight, were used in the experiment and randomly distributed into four groups according to treatment: only Panicum maximum cv. Mombasa grass; Mombasa grass with concentrated supplementation based on soybean meal; Mombasa grass with concentrate containing lipids from soybean oil; and Mombasa grass with concentrate containing lipids derived from soybean grains. There were no differences $(P>0.05)$ between the treatments for temperature, $\mathrm{pH}$, thawing, cooking and total losses, shear force, sarcomere length and collagen in bulls. Nellore young bulls raised in fertilized and irrigated Mombasa grass fed Mombasa grass only or supplemented with or without addition of lipids were similar regarding meat quality.
\end{abstract}

KEYWORDS: Beef cattle. Collagen. Tenderness.

\section{INTRODUCTION}

The Brazilian beef industry is specialized in raising grass-fed cattle, however, due to variations in the quantity and quality of forage offered, the performance of the animals can be compromised (SANTANA et al., 2017). Supplementation of grazing cattle is a common practice used to improve performance as well as the quality of the meat produced (CARVALHO et al., 2017). Among the various types of supplements available, lipid supplements have stood out, since they increase the energy density of the diets and improve the quality of the meat of the cattle (FIORENTINI et al., 2015), increasing tenderness and juiciness of the product (PHOEMCHALARD; URIYAPONGSON, 2015).

Thus, as lipid supplementation can positively impact meat quality, such forms of supplementation have been the focus of study, as the requirements imposed for the physicochemical characteristics of meat for consumer markets have increased steadily. Highlighting the variables related to meat tenderness, as it is considered one of the main qualities of meat and is directly involved with the highest acceptability of consumers (DOMINGUEZ-HERNANDEZ; SALASEVICIENE; ERTBJERG, 2018).
Thus, it was hypothesized that Nellore bulls supplemented with the addition of lipids, regardless of source, could exhibit improved meat quality of young Nellore bulls in grazing. This study aimed to evaluate the effect of supplementation with or without the addition of lipids in the feed of Nellore bulls on physicochemical characteristics of meat.

\section{MATERIAL AND METHODS}

Ethical considerations and the location of the experiment

This study was performed in strict accordance with the recommendations in the Guide for the National Council for Animal Experiments Control and approved by the Committee on the Ethics of Animal Experiments of the State University of North Fluminense, Rio de Janeiro State, Brazil (Permit Number: 168-2012).

\section{Experimental treatments}

The experimental area was divided into two 4.5-hectare blocks (replicate areas) equipped with an irrigation sprinkler system grid and divided into 18 paddocks of 0.25 ha. Due to the reduced rainfall in the period, pasture irrigation was performed at intervals of seven days. The Mombasa grass was 
Physicochemical...

fertilized by the application of $100 \mathrm{~kg} \mathrm{~N}$ and $50 \mathrm{~kg}$ $\mathrm{K}_{2} \mathrm{O} / \mathrm{ha} /$ year and fractionated after each grazing cycle, depending on the weather conditions (temperature, rainfall, and solar radiation). The animals were adapted for a period of 21 days to the experimental procedures and supplementation.

Mombasa grass was managed under a rotational grazing system, with periods of occupation and rest of two and 34 days, respectively, representing a grazing cycle of 36 days, the experiment totalized 180 days (5 cycles).A variable stocking rate (put and take) was adopted to maintain the supply of biomass of green leaf blades at $4 \mathrm{~kg} \mathrm{DM} / 100 \mathrm{~kg}$ body weight of the animals.

Twenty-four Nellore young bulls were used in the experiment, with an average weight of 300.6 $\pm 5.8 \mathrm{~kg}$ and an average age of 15 months. The animals were randomly distributed into four groups of six animals. Four groups were allocated at random to each replicate area of each of the following treatments: Control - only Mombasa grass (Panicum maximum); Soybean Meal (Mombasa grass with concentrated supplementation based on soybean meal); Soybean Oil (Mombasa grass with concentrated containing lipids from soybean oil); and Soybean Grain (Mombasa grass with concentrate containing lipids derived from soybean grains).

\section{SILVEIRA FILHO, C. C.et al}

The supplements were offered in an individual stall $\left(10.2 \mathrm{~m}^{2}\right)$ with masonry feeders and automatic water troughs. In the adaptation period, the animals were weighed, treated for internal and external parasites (IVOMEC GOLD®, MERIAL, SÃO PAULO, BRAZIL) and received subcutaneous administration of vitamin A $(1,500,000$ IU per head).

Mombasa grass intake was allowed ad libitum. The supplements were provided in TMR at a ratio of $0.75 \mathrm{~kg}$ concentrate $/ 100 \mathrm{~kg}$ of $\mathrm{BW}$ in DM and once per day at 9:00 $\mathrm{h}$, before the animals were returned to the Mombasa grass, where they remained the rest of the day. Assuming ad libitum forage intake and the total dry matter intake corresponding to $2.5 \mathrm{~kg}$ per $100 \mathrm{~kg}$ body weight per day, the diet would consist of $0.75 \mathrm{~kg}$ of concentrate and $1.75 \mathrm{~kg}$ of roughage per $100 \mathrm{~kg}$ body weight, corresponding to the ratio of forage: concentrate of 70:30 in DM. The diets were formulated based on the composition of DM in order to meet the requirements of the bulls according to the NRC (2000). Animals in the control treatment were subjected to the same handling, receiving only mineral supplements during the period in the stall. The proportion of ingredients and the chemical composition are shown in Table 1.

Table 1. Ingredients and chemical composition of supplements and pasture.

\begin{tabular}{|c|c|c|c|c|}
\hline \multirow{2}{*}{ Ingredients } & \multicolumn{4}{|c|}{ Treatments } \\
\hline & Mombasa grass & Soybean meal & Soybean oil & Soybean grain \\
\hline Soybean grain & - & - & - & 54.8 \\
\hline Ground corn & - & 56.3 & 43.7 & 43.4 \\
\hline soybean oil & - & - & 10.3 & - \\
\hline Mixed minerals ${ }^{\mathrm{A}}$ & 2.00 & 2.00 & 2.00 & 1.80 \\
\hline Soybean Meal & - & 41.7 & 44.0 & - \\
\hline Total & 100 & 100 & 100 & 100 \\
\hline \multicolumn{5}{|c|}{ Chemical composition $(\% \mathrm{DM})$} \\
\hline Dry Matter & 23.1 & 28.4 & 28.5 & 28.5 \\
\hline Crude Protein ${ }^{\mathrm{B}}$ & 10.0 & 14.6 & 14.6 & 14.6 \\
\hline Ether Extract ${ }^{\mathrm{B}}$ & 1.00 & 1.60 & 4.50 & 4.50 \\
\hline Neutral detergent fiber ${ }^{\mathrm{B}}$ & 66.0 & 52.6 & 52.2 & 52.3 \\
\hline Total digestible nutrient ${ }^{\mathrm{B}}$ & 51.0 & 60.6 & 64.0 & 60.9 \\
\hline Calcium $^{\mathrm{B}}$ & 0.70 & 0.70 & 0.70 & 0.70 \\
\hline Phosphorus ${ }^{\mathrm{B}}$ & 0.20 & 0.20 & 0.30 & 0.30 \\
\hline
\end{tabular}

\section{Slaughter and obtaining samples}

Nellore bulls were weighed after $16 \mathrm{~h}$ fasting day, stunned with a captive bolt pistol, suspended by upside down, and bled through the jugular vein. The $\mathrm{pH}$ was measured $24 \mathrm{~h}$ after slaughter in the longissimus dorsi muscle using a Mettler M1120x pH meter (Mettler Toledo International Inc., Columbus, Ohio, United States) following the procedures described by AOAC (2000). The carcasses were divided in half with the 
aid of a chainsaw and after cooling the two halfcarcasses, two samples were taken from the Longissimus dorsi, then, the samples were identified and frozen at $-15{ }^{\circ} \mathrm{C}$. Subsequently, the samples were placed in polystyrene boxes and shipped frozen to the Animal Science Department of Federal University of Viçosa, Brazil.

\section{Thawing, cooking and total losses}

For the analyses of losses, the samples used (steaks) were Longissimus dorsi and were still frozen. These samples were selected with the aid of a stainless-steel table bone saw (INDUSTRIAL BECKER, SÃO PAULO, BRAZIL) and a ruler to yield steaks $2.54 \mathrm{~cm}$ thick. The steaks were then thawed for $16 \mathrm{~h}$ at a temperature of $4{ }^{\circ} \mathrm{C}$. They were weighed before and after thawing to determine thawing losses. Then, the steaks were baked in a preheated electric oven (GRILL GEORGE FOREMAN JUMBO GBZ6BW, RIO DE JANEIRO, BRAZIL), and the internal temperature of the steaks was monitored with the aid of a thermometer with probe type $\mathrm{K}$, positioned at the geometric center of each steak. The steaks were removed from the electric broiler (GRL297 127V CADENCE®, SÃO PAULO, BRAZIL) at the time when the internal temperature reached $71{ }^{\circ} \mathrm{C}$. The cooking losses were obtained by weighing the steak after being baked, following American Meat Science Association recommendations (AMSA, 2015). Total losses were obtained by the weight difference between the frozen samples and after being baked.

\section{Shear force, sarcomere length and collagen}

The shear force was determined with the Warner-Bratzler ShearForce unit (GR ELECTRICAL MANUFACTURING COMPANY, MINAS GERAIS, BRAZIL) equipped with a Warner-Bratzler blade with a $25-\mathrm{kg}$ capacity and a shearing speed of $20 \mathrm{~cm} / \mathrm{min}$. six cylindrical samples were removed from each steak in the direction of muscle fibers of approximately $13 \mathrm{~mm}$ in diameter done by a manual punch as described by AMSA (2015).

Sarcomere length was measured with approximately $1 \mathrm{~g}$ of the central portion of the sample from the Longissimus dorsi muscle (between 12 th and 13th ribs) removed with forceps and a scalpel and immersed in $0.2 M$ buffered sucrose according to the method of Cross, West and Dutson (1981). The sample was then mounted in a tissue chamber and sarcomere length was measured with a helium-neon laser $(1 \mathrm{~mW})$ at a wavelength of 632.8 nm.
Collagen were quantified by the determination of hydroxyproline, as described by Woessner Junior (1961). The samples were hydrolyzed in an autoclave at $120{ }^{\circ} \mathrm{C}$ and $1 \mathrm{~atm}$ for 4 h (CROSS; CARPENTER; SMITH, 1973).

\section{Statistical analyses}

Statistical analyses were performed using the following model: $Y_{i j}=\mu+T_{i}+R_{j}+T_{i j}+\varepsilon_{i j}$, using the Nellore steer as the experimental unit, where $\mathrm{Y}_{\mathrm{ij}}=$ observation concerning the animal, receiving treatment $i$ in replicate area $j ; \mu$ is average; $\mathrm{T}_{\mathrm{i}}=$ treatment effect $\mathrm{i}$, where $\mathrm{i}$ is control (Mombasa grass), soybean meal concentrate, soybean oil concentrate and soybean grain concentrate; $R \mathrm{j}=$ area of repeat effect, where $\mathrm{j}=1,2 ; \mathrm{TR}_{\mathrm{ij}}=$ the interaction effect between treatment $\mathrm{i}$ and $\mathrm{j}$ replicate area; and cij = random error.

In the statistical analysis, we used the PROC GLM procedure of SAS (2004) and the means were compared by using Tukey's test $(\mathrm{P}<0.05)$. Treatments were compared using three orthogonal contrasts. The first comparison made among the three treatments involved supplementation with concentrate and the control treatment. The second comparison was between the treatment supplemented with or without lipids (soybean meal versus soybean oil and soybean grain), and the third comparison was between the lipids sources in the supplementation (soybean oil versus soybean grain).

\section{RESULTS}

\section{Physicochemical characteristics}

There were no differences between Mombasa grass and diets with concentrate $(\mathrm{P}=0.70)$, supplementation with or without lipids $(\mathrm{P}=0.70)$ and lipids sources $(\mathrm{P}=0.47)$ on the temperature (Table 2 ). The $\mathrm{pH}$ values found between Mombasa grass and diets with concentrate $(\mathrm{P}=0.77)$ and supplementation with or without lipid $(\mathrm{P}=0.34)$ and lipids sources $(\mathrm{P}=0.13)$ were similar, with mean of 5.55 .

There was no interaction effect between Mombasa grass and diets with concentrate for the variables thawing losses $(\mathrm{P}=0.86)$, cooking losses $(\mathrm{P}=0.63)$, total losses $(\mathrm{P}=0.68)$, shear force $(\mathrm{P}=0.16)$, sarcomere length $(\mathrm{P}=0.77)$, and total collagen $\%$ and $\mathrm{mg} / \mathrm{g}(\mathrm{P}=0.14)$ (Table 2). The supplementation with or without lipid and lipids sources did not influence any variables $(\mathrm{P}=0.05)$. 
Table 2. Temperature, $\mathrm{pH}$, thawing, cooking and total losses $(\%)$, shear force $\left(\mathrm{kgf} / \mathrm{cm}^{2}\right)$, index $(\%)$, sarcomere length $\left(\mathrm{cm}^{2}\right)$, total and soluble collagen $(\% ; \mathrm{mg} / \mathrm{g})$ of Nellore bulls supplemented with different soybean byproduct concentrates.

\begin{tabular}{|c|c|c|c|c|c|c|c|c|}
\hline \multirow[b]{2}{*}{ Item } & \multicolumn{4}{|l|}{ Treatments } & \multirow[b]{2}{*}{$\mathrm{SEM}^{\mathrm{A}}$} & \multicolumn{3}{|c|}{ P-value ${ }^{B}$} \\
\hline & $\begin{array}{l}\text { Mombasa } \\
\text { grass }\end{array}$ & $\begin{array}{l}\text { Soybean } \\
\text { meal }\end{array}$ & $\begin{array}{l}\text { Soybean } \\
\text { oil }\end{array}$ & $\begin{array}{l}\text { Soybean } \\
\text { grain }\end{array}$ & & $\begin{array}{l}\text { MG vs } \\
\text { S }\end{array}$ & $\begin{array}{l}\mathrm{SM} v s \\
\mathrm{SO}+\mathrm{SG}\end{array}$ & $\begin{array}{l}\mathrm{SO} v s \\
\mathrm{SG}\end{array}$ \\
\hline Temperature ${ }^{\circ} \mathrm{C}$ & $7.50 \pm 0.60$ & $8.30 \pm 0.60$ & $8.10 \pm 0.60$ & $7.80 \pm 0.60$ & 1.07 & $0.47^{\mathrm{ns}}$ & $0.70^{\mathrm{ns}}$ & $0.70^{\mathrm{ns}}$ \\
\hline $\mathrm{pH}$ & $5.50 \pm 0.00$ & $5.60 \pm 0.00$ & $5.60 \pm 0.00$ & $5.50 \pm 0.00$ & 1.01 & $0.77^{\mathrm{ns}}$ & $0.34^{\mathrm{ns}}$ & $0.13^{\mathrm{ns}}$ \\
\hline $\begin{array}{l}\text { Thawing losses, } \\
\%\end{array}$ & $23.5 \pm 1.20$ & $23.8 \pm 1.20$ & $24.1 \pm 1.20$ & $21.8 \pm 1.20$ & 1.41 & $0.86^{\mathrm{ns}}$ & $0.56^{\mathrm{ns}}$ & $0.20^{\mathrm{ns}}$ \\
\hline $\begin{array}{l}\text { Cooking losses, } \\
\%\end{array}$ & $19.5 \pm 1.20$ & $20.5 \pm 1.20$ & $20.9 \pm 1.20$ & $18.9 \pm 1.20$ & 5.98 & $0.63^{\mathrm{ns}}$ & $0.70^{\mathrm{ns}}$ & $0.25^{\mathrm{ns}}$ \\
\hline Total losses, $\%$ & $43.0 \pm 1.20$ & $44.3 \pm 1.20$ & $45.0 \pm 1.20$ & $40.7 \pm 1.20$ & 4.89 & $0.68^{\mathrm{ns}}$ & $0.53^{\mathrm{ns}}$ & $0.14^{\mathrm{ns}}$ \\
\hline $\begin{array}{l}\text { Shear force, kgf } \\
/ \mathrm{cm}^{2}\end{array}$ & $5.80 \pm 0.40$ & $5.20 \pm 0.40$ & $5.10 \pm 0.40$ & $4.80 \pm 0.40$ & 1.11 & $0.16^{\mathrm{ns}}$ & $0.59^{\mathrm{ns}}$ & $0.63^{\mathrm{ns}}$ \\
\hline $\begin{array}{l}\text { Sarcomere } \\
\text { length, } \mathrm{cm}^{2}\end{array}$ & $1.40 \pm 0.00$ & $1.40 \pm 0.00$ & $1.40 \pm 0.00$ & $1.40 \pm 0.00$ & 0.11 & $0.77^{\mathrm{ns}}$ & $0.95^{\mathrm{ns}}$ & $0.54^{\mathrm{ns}}$ \\
\hline $\begin{array}{l}\text { Total Collagen, } \\
\%\end{array}$ & $3.00 \pm 0.20$ & $2.60 \pm 0.20$ & $2.70 \pm 0.20$ & $2.70 \pm 0.20$ & 0.16 & $0.14^{\mathrm{ns}}$ & $0.69^{\mathrm{ns}}$ & $0.75^{\mathrm{ns}}$ \\
\hline $\begin{array}{l}\text { Total Collagen, } \\
\mathrm{mg} / \mathrm{g}\end{array}$ & $30.1 \pm 1.70$ & $26.4 \pm 1.70$ & $27.6 \pm 1.70$ & $26.8 \pm 1.70$ & 1.69 & $0.14^{\mathrm{ns}}$ & $0.69^{\mathrm{ns}}$ & $0.75^{\mathrm{ns}}$ \\
\hline
\end{tabular}

\section{DISCUSSION}

\section{Physicochemical characteristics}

The temperature and $\mathrm{pH}$ were similar all carcasses. The average $\mathrm{pH}$ values for the carcasses subjected to various treatments remained in the range of 5.5 to 5.6 after 24 hours of cooling (Table 2 ). The final $\mathrm{pH}$ is dependent on the lactic acid accumulation resulting from adenosine triphosphate production by using glycogen as a source of glucose (Oliveira et al., 2011), indicating that muscle glycogen levels before slaughter remained appropriate, allowing the normal development of glycolysis in all treatments. In addition, they suggest that there was no pre-slaughter stress. Due to this similarity on final $\mathrm{pH}$, there was also no effect of supplementation on cooking, cooling and total losses, as these variables are affected as a result of $\mathrm{pH}$ variation (OLIVEIRA et al., 2018). Indicating that juiciness, which is one of the qualitative attributes emphasized by consumers, remained similar among the diets tested.

The shear force, sarcomere length, and collagen are parameters that have direct relationships with the tenderness of the meat; they did not differ among treatments $(\mathrm{P}>0.05)$ (Table 4). Additionally, it is important to note that the rate of weight gain may affect muscle protein renewal in vivo and, consequently, postmortem muscle proteolysis and meat tenderness (KRISTENSEN et al., 2002; THERKILDSEN; HOUBAK; BYRNE, 2008). In addition, the age of the animals is also important because as they age, even with the same concentration of collagen, the number of thermostable muscle collagen crosslinks increases (MOHOLISA et al., 2017), which could increase shear force. and reflect negatively on meat quality. However, in this experiment the animals were the same age and did not differ in relation to weight gain, which corroborates with similar shear force. Lastly, the shear force values observed in this study were at the threshold or above the amounts stipulated $\left(4.6 \mathrm{kgf} / \mathrm{cm}^{2}\right)$ for tender meat (SHACKELFORD et al., 1991).

\section{CONCLUSION}

Young Nellore bulls feeding on fertilized and irrigated Mombasa grass only or supplemented with or without addition of lipids were similar regarding physicochemical characteristics of meat.

\section{CONFLICTS OF INTEREST}

The authors declare they have no conflicts of interest regarding the work presented in this report. 
RESUMO: Objetivou-se com esta pesquisa avaliar a qualidade da carne de novilhos Nelore em pastejo suplementado com ou sem adição de lipídios. Vinte e quatro novilhos, $301 \pm 5,8 \mathrm{~kg}$ de peso vivo, foram utilizados no experimento e distribuídos aleatoriamente em quatro grupos de acordo com os tratamentos: somente Panicum maximum cv. capim-mombaça; capim-mombaça com suplementação concentrada à base de farelo de soja; capim-mombaça com concentrado contendo lipídios do óleo de soja; e capim-mombaça com concentrado contendo lipídios derivados de grãos de soja. Não houve diferenças $(\mathrm{P}>0,05)$ entre os tratamentos para temperatura, $\mathrm{pH}$, perdas por descongelamento, perdas por cozimento e perdas totais, força de cisalhamento, comprimento de sarcômero e colágeno nos touros. Novilhos Nelore criados em capim-mombaça fertilizado e irrigado, alimentados apenas com capim-mombaça ou suplementados com ou sem adição de lipídeos, foram semelhantes quanto à qualidade da carne.

PALAVRAS-CHAVE: Colágeno. Gado de corte. Maciez.

\section{REFERENCES}

AMSA. Research guidelines for cookery, sensory evaluation, and instrumental tenderness measurements of meat. American Meat Science Association 2nd edition (version 1.0). 2015.

AOAC. Official Methods of Analysis, 15th ed. Assoc. Off. Anal. Chem., Gaithersburg, VA, USA. 2000.

CARVALHO, I. P. C.; FIORENTINI, G.; LAGE, J. F.; MESSANA, J. D.; CANESIN, R. C.; ROSSI, L. G.; REIS, R. A.; BERCHIELLI, T. T. Fatty acid profile, carcass traits and meat quality of Nellore steers following supplementation with various lipid sources. Animal Production Science, v. 57, n. 6, p. 1170-1178, 2017. http://dx.doi.org/doi:10.1071/AN15149

CROSS, H. R.; CARPENTER, Z. L.; SMITH, G. C. Effects of intramuscular collagen and elastin on bovine muscle tenderness. Journal of Food Science, v.38, n. 6, p.998-1003, 1973.

http://dx.doi.org/doi:10.1111/j.1365-2621.1973.tb02133.x

CROSS, H. R.; WEST, R. L.; DUTSON, T. R. Comparison of methods for measuring sarcomere length in beed semitendinosus muscle. Meat Science, v. 5, n. 4, p. 261-266, 1981. http://dx.doi.org/doi:10.1016/03091740(81)90016-4

DOMINGUEZ-HERNANDEZ, E.; SALASEVICIENE, A.; ERTBJERG, P. Low-temperature long-time cooking of meat: Eating quality and underlying mechanisms. Meat science, v. 143, p. 104-113, 2018. https://doi.org/10.1016/j.meatsci.2018.04.032

FIORENTINI, G.; LAGE, J. F.; CARVALHO, I. P. C.; MESSANA, J. D.; CANESIN, R. C.; REIS, R. A.; BERCHIELLI, T. T. Lipid sources with different fatty acid profile alters the fatty acid profile and quality of beef from confined Nellore steers. Asian-Australasian journal of animal sciences, v. 28, n. 7, p. 976-986, 2015. http://dx.doi.org/doi:10.5713/ajas.14.0893

KRISTENSEN, L.; THERKILDSEN, M.; RIIS, B.; SØRENSEN, M. T.; OKSBJERG, N.; PURSLOW, P. P.; ERTBJERG, P. Dietary-induced changes of muscle growth rate in pigs: Effects on in vivo and postmortem muscle proteolysis and meat quality. Journal of animal science, v. 80, n. 11, p. 2862-2871, 2002. https://doi.org/10.2527/2002.80112862x

MOHOLISA, E.; HUGO, A.; STRYDOM, P. E.; VAN HEERDEN, I. The effects of animal age, feeding regime and a dietary beta-agonist on tenderness of three beef muscles. Journal of the Science of Food and Agriculture, v. 97, n. 8, p. 2375-2381, 2017. https://doi.org/10.1002/jsfa.8049

NRC - Nutrient Requirements of Beef Cattle, 7th ed. National Academy Press, National Research Council, Washington, USA, 2000. 359 p. 
PHOEMCHALARD, C.; URIYAPONGSON, S. Effect of cassava bioethanol by-product and crude palm oil in Brahman $\mathrm{x}$ Thai native yearling heifer cattle diets: II. Carcass characteristics and meat quality. Tropical Animal Health and Production, v. 49, n. 8, p. 1-3, 2015. http://dx.doi.org/doi: 10.1007/s11250-015-0902-8

SANTANA, M. C. A.; MESSANA, J. D.; FIORENTINI, G.; LAGE, J. F.; DIAN, P. H. M.; CANESIN, R. C.; REIS, R. A.; BERCHIELLI, T. T. Characteristics of carcass and meat of heifers finished on pasture amended with different supplement frequency and soybean oil source, Canadian Journal of Animal Science, v.98, n.0, p.32-43, 2017. http://dx.doi.org/doi:10.1139/cjas-2016-0185

SAS Institute - Inc. SAS/STAT User’s guide. Version 9.1, Cary, NC: SAS Institute Inc. 2004.

SHACKELFORD, S. D.; KOOHMARAIE, M.; MILLER, M. F.; CROUSE, J. D.; REAGAN, J. O. An evaluation of tenderness of the longissimus muscle of Angus by Hereford versus Brahman crossbred heifers. Journal of Animal Science, v. 69, n. 1, p.171-177, 1991. http://dx.doi.org/doi: 10.2527/1991.691171x

THERKILDSEN, M.; HOUBAK, M. B.; BYRNE, D. V. Feeding strategy for improving tenderness has opposite effects in two different muscles. Meat science, v. 80, n. 4, p. 1037-1045, 2008. https://doi.org/10.1016/j.meatsci.2008.04.023

WOESSNER JUNIOR, J. F. The determination of hydroxyproline in tissue and protein samples containing small proportions of this amino acid. Archives of Biochemistry and Biophysics, v. 93, n. 2, p. 440-447, 1961. http://dx.doi.org/doi: 10.1016/0003-9861(61)90291-0 